\title{
Strategy for Handling Flood Inundation in the Area of Jalan Bundaran PU Kelurahan Tuak Daun Merah Kota Kupang
}

\author{
Priska Gardeni Nahak ${ }^{1}$, Anastasia H. Muda ${ }^{1}$ dan Dessy D. A. A. Daud ${ }^{1}$ \\ \{prigardeni@yahoo.com, anasta_hendrian@yahoo.com,dessydaud@yahoo.com\} \\ Civil Engineering Department Kupang State Polytechnic ${ }^{1}$
}

\begin{abstract}
Flooding in the Kupang City is considerably alarming. One of the area that often experiences inundation when it rains is the area of Tuak Daun Merah village, especially at the PU roundabout. Inundated flooding at this location occurs due to the transformation in the rain catchment area into a residential area and a commercial center. This research aims to mitigate the flood issue at PU roundabout area with an eco-drainage approach to conserving the water under the ground. Based on the results of the analysis, it is known that the discharge plan for the runoff flood every two years is $Q=0,0555 \mathrm{~m} 3 / \mathrm{sec}$. To reduce the runoff discharge at $\mathrm{Q}=0,0555 \mathrm{~m} 3 / \mathrm{sec}, 172$ pieces of infiltration wells are required with the 2 meters depth measure of the well and 0.5 meters rays. This infiltration well will be allocated into 3 locations on the left and right side of the road.
\end{abstract}

Key words: Flood inundation, mitigation concept, eco drainage, infiltration well

\section{Introduction}

As the capital of the province, the Kupang city has become one of the major targets for urbanization. This can be seen from the number of catchment areas such as forest areas, agricultural areas, and green open areas have now been converted into residential areas, offices and commercial areas. Those mentioned changes in the catchment area become the main reasons that impedes the rainwater to soak into the ground and increase the flow of surface run off which eventually flood / inundate the basin areas and lower lying areas.

The PU Roundabout area in Tuak Daun Merah village one of the location in the Kupang city which often experiences flooding when it rains. This happens because most of these areas of this location have not yet been placed the drainage channels, which affects the runoff water flow through the highway and inundate the basin areas along the PU roundabout. This also led to a higher possibility to form holes of the roads which could expose to accidents. 
Therefore, it is suggested to apply the eco drainage approach as its mitigation strategy for inundated flood in the areas of PU roundabout, TDM village, Kupang. This mitigation strategy can help to prevent the runoff water not to flow directly to the river or sea, which in turn the water will be conserved and absorbed into the ground. This is considered as a method to conserve the underground water, which will also be corresponding to the common issue of the Kupang City as an area that is prone to drought.

\section{Eco drainage}

Eco-drainage or environmentally friendly drainage is defined as an effort to cope with the excess water (rain water) by various means, which includes storing the water in reservoirs that will then be reused immediately, storing in artificial reservoirs or natural reservoirs, infiltrating and streaming into nearby rivers without adding pressure to the river and always help maintaining the condition of the natural environment in a sustainable manner. [1]

With the above mentioned environmentally friendly concept, it will reduce the quantity of the water wasted to the sea quickly. In reverse, the rainwater can be stored in various locations in the concerned area by multiple ways, in order to enabling the effective retention of the water in the following season, infiltrated or conserved into the ground, to improve the quality of the surrounding ecosystems and the environment, as well as a method to reduce inundation or the existing flooding. With this environmentally friendly drainage system, the drought on the upstream area can be prevented, and minimizing the chance for flooding or inundation at the concerned location, mainly in the downstream areas. [2]

There are several environmentally friendly methods have applied in Indonesia and some among them are infiltration trenches, infiltration wells, and rorak [3]. Infiltration well is an effort to absorb rainwater in order to increase groundwater reserves [4]

\section{Flood Discharge Analysis}

Calculation of flood discharge analysis is preceded by the calculation of the average rainfall in the area. According to [5] [6] [7]: there are three methods that can be used, namely the algebraic average method, the Thiesen polygon method and the Isohyet method. Furthermore, based on rainfall data the value of the planned rainfall or plan discharge is calculated using frequency analysis.

Determination of the type of probability distribution that is equivalent to the data is done by matching the parameters of the data with the criteria of each distribution type.

Probability distribution test is intended to find out whether the selected probability distribution equation can represent the statistical distribution of the sample of the analyzed data.

There are two methods of testing the probability distribution, namely: the Chi Kuadrat (X2) method and the Smirnov-Kolmogorov method,) [8]

One of the Empirical methods for calculating the discharge of the runoff flood that occurs is the Rational method. The mathematical equation of the Rational method is expressed in the form, [8]:

$$
\mathrm{Q}=0,278 \times \mathrm{C} \times \mathrm{I} \times \mathrm{A}
$$

Descriptions:

$\mathrm{Q}=$ peak runoff surface discharge $\left(\mathrm{m}^{3} / \mathrm{sec}\right)$

$\mathrm{C}=$ flow rate (without dimensions) 
$\mathrm{I}=$ rainfall intensity $(\mathrm{mm} /$ hour$)$

$\mathrm{A}=$ area of drainage area $\left(\mathrm{Km}^{2}\right)$

\section{General description of the study area}

The location of the study is on the PU Roundabout, Tuak Daun Merah Village, Oebobo Subdistrict, Kupang City. the length of the road reviewed is $2.95 \mathrm{~km}$, starting from the Soverdi intersection to the Hypermart PU roundabout.

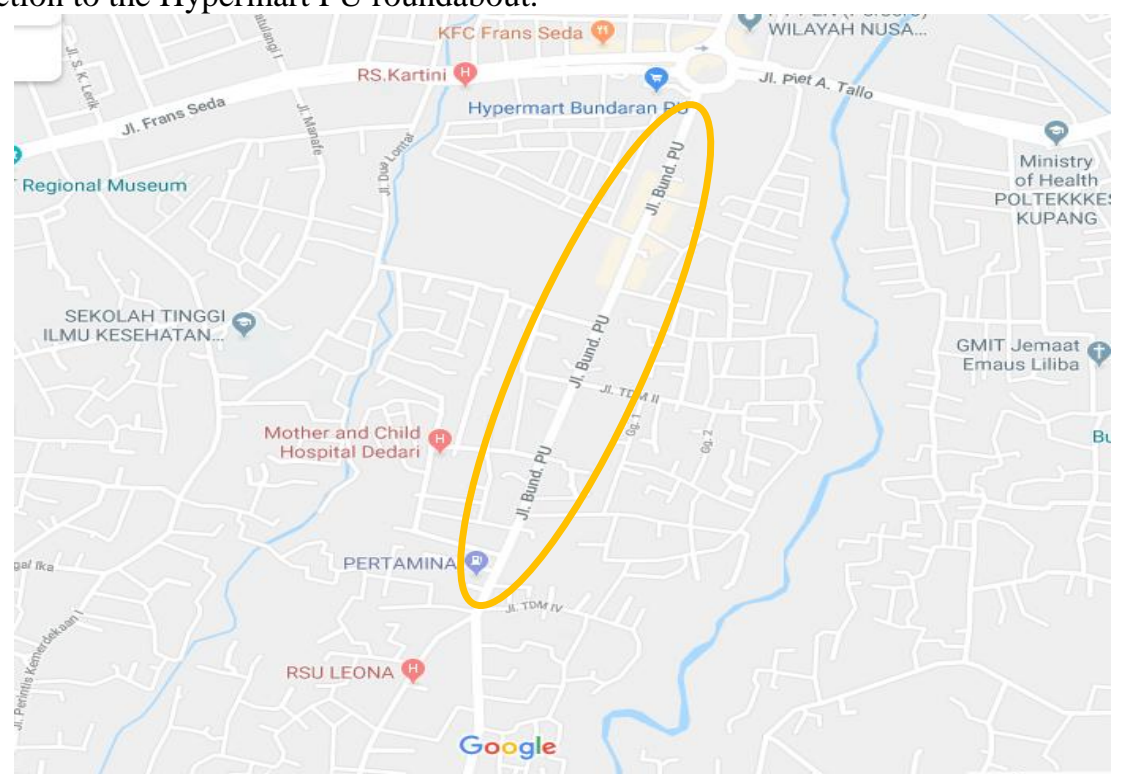

Figure 2. Research location of the Roundabout Road Section of PU

Issues that can be seen on the PU roundabout are:

1. Only a small portion of this road has a drainage channel that is only $1000 \mathrm{~m}$ along the direction of the PU roundabout. Whereas, around $1500 \mathrm{~m}$ area is lack of a drainage which becomes the obstacle for the run-off water to flow into the channel, rather than cause the water flows over the the road which also eventually damages or erodes the edges of the road.

2. Majority of these roads do not have the sidewalks yet, which affect the water to flow in the wrong direction and eventually erodes the soil and the edges of the road.

3. The condition of the road body is following the irregular topography, which affects inundation in the section of the road in the basin location. Some locations that always experience inundation can be seen in the picture. 


\section{Result and Discussion}

\subsection{Hydrological Analysis}

Rainfall data which is used in this study is the daily rainfall data for observations over the past 10 years, namely from 2009 to 2018. The use of the Rainfall data is maximum daily rainfall data from the three closest stations namely Sta Penfui, Sta Lasiana and Sta Sikumana From the rainfall data, what is taken is the largest rainfall data in each observation year and the data can be seen in table 1 below:

Table 1 Annual Maximum Rainfall Data

\begin{tabular}{|c|c|c|c|}
\hline Year & $\begin{array}{c}\text { Penfui station } \\
(\mathbf{m m})\end{array}$ & $\begin{array}{c}\text { Lasiana Station } \\
(\mathbf{m m})\end{array}$ & $\begin{array}{c}\text { Sikumana station } \\
(\mathbf{m m})\end{array}$ \\
\hline 2009 & 89 & 228 & 56 \\
\hline 2010 & 145 & 133 & 138 \\
\hline 2011 & 120 & 107 & 118 \\
\hline 2012 & 66 & 180 & 140 \\
\hline 2013 & 18 & 253 & 57 \\
\hline 2014 & 36 & 296 & 95 \\
\hline 2015 & 122 & 168 & 118 \\
\hline 2016 & 110 & 154 & 119 \\
\hline 2017 & 90 & 192 & 137 \\
\hline 2018 & 98 & 112 & 60 \\
\hline
\end{tabular}

Source: $\mathrm{BMKG}$

\subsection{Calculation of the average of the maximum rain}

The data in the table 1 is then processed into average daily rainfall data using the algebraic average method to get the maximum average rainfall. After obtaining the maximum daily rainfall data, the distribution was tested using an appropriate method. Then it was tested with the Chi-Squared Method and the Smirnov-Kolmogorov Method. After passing the Chi-Square Test and Smirnov Kolmogorov, then the probability distribution can be used to calculate the rainfall plan.

Table 2 Calculation of Maximum Rain Average Table

\begin{tabular}{|c|c|c|c|c|}
\hline Year & $\begin{array}{c}\text { Penfui station } \\
(\mathbf{m m})\end{array}$ & $\begin{array}{c}\text { Lasiana } \\
\text { station } \\
(\mathbf{m m})\end{array}$ & $\begin{array}{c}\text { Sikumana } \\
\text { Station } \\
(\mathbf{m m})\end{array}$ & $\begin{array}{c}\text { Rain Maximum } \\
\text { Average } \\
(\mathbf{m m})\end{array}$ \\
\hline 2009 & 89 & 228 & 56 & 124,3 \\
\hline 2010 & 145 & 133 & 138 & 138,7 \\
\hline 2011 & 120 & 107 & 118 & 115,0 \\
\hline 2012 & 66 & 180 & 140 & 128,7 \\
\hline 2013 & 18 & 253 & 57 & 109,3 \\
\hline 2014 & 36 & 296 & 95 & 142,3 \\
\hline 2015 & 122 & 168 & 118 & 136,0 \\
\hline 2016 & 110 & 154 & 119 & 127,7 \\
\hline 2017 & 90 & 192 & 137 & 124,3 \\
\hline 2018 & 98 & 112 & 60 & 90 \\
\hline
\end{tabular}




\subsection{Calculation of the rainfall Plans}

The available rainfall data is tested for consistency using a double mass curve, then after passing the consistency test the data is valid for use. This data is then processed into average daily rainfall data using the algebraic average method to obtain maximum average rainfall. After obtaining the maximum daily rainfall data, the distribution was tested using an appropriate method. Then it was tested with the Chi-Squared Method and the Smirnov-Kolmogorov Method. After passing the Chi-Square Test and Smirnov Kolmogorov, then the probability distribution can be used to calculate the rainfall plan. Based on the analysis results, the value of Rainfall Plan for the 2-year return period is $=122.95 \mathrm{~mm}$

The intensity of the rain:

$I=\frac{R}{24}\left(\frac{24}{t_{c}}\right)^{2 / 3}$

Road slope calculation:

$S=\frac{H}{0,9 \times L}$

$S=\frac{80-65}{0,9 \times 1200}$

$S=0,0138$

Concentration time

$t_{c}=\left(\frac{0,87 \times L^{2}}{1000 \times S}\right)^{0,385}$

$t_{c}=\left(\frac{0,87 \times 1200^{2}}{1000 \times 0,0138}\right)^{0,385}$

$t_{c}=81,065 \mathrm{Jam}$

Rainfall intensity

$I=\frac{R}{24}\left(\frac{24}{t_{c}}\right)^{2 / 3}$

$I=\frac{122,95}{24}\left(\frac{24}{81,065}\right)^{2 / 3}$

$I=2,276 \mathrm{~mm} / \mathrm{jam}$

Run off Flood Plan Discharge

$\mathrm{Q}=0,00278 \times \mathrm{C} \times \mathrm{I} \times \mathrm{A}$

$=0,00278 \times 0,75 \times 2,276 \times 11,6865 \mathrm{Ha}$

$=0,0555 \mathrm{~m}^{3} / \mathrm{det}$

Description:

$\mathrm{Q}=$ debit puncak $/$ maksimum (m3/det)

$\mathrm{C}=$ koefisien limpasan aliran permukaan

$\mathrm{I}=$ intensitas hujan $(\mathrm{mm} / \mathrm{jam})$

$\mathrm{A}=$ luas daerah aliran $(\mathrm{Ha})$ 


\subsection{Infiltration Well Planning}

Based on the field conditions, there are 3 basin locations that are considered the location of stagnant water runoff when it rains, namely the intersection of the Sinar Shop building ( $\mathrm{L}=$ $480.94 \mathrm{~m})$, the RSIA Dedari intersection $(\mathrm{L}=873.37 \mathrm{~m})$, and the TDM II intersection ( $\mathrm{L}=$ $1200 \mathrm{~m})$. Therefore it is planned that infiltration wells to be placed at these three locations to reduce the amount of runoff water that is concentrated at one point or location.

$$
\begin{aligned}
& \text { Infiltration Wells Capacity } \\
& \begin{aligned}
\hline \mathrm{Q}_{\text {sr }} & =\text { C.I. A } \\
& =0.95 \times 0.094 \times 12.71 \\
& =1.135 \mathrm{~m} 3 / \text { hour }
\end{aligned}
\end{aligned}
$$

Descritions:

$\mathrm{Q}_{\mathrm{sr}}=$ well water discharge / well discharge $\mathrm{m} 3$ / hour)

$\mathrm{A}=$ area of house roof $(\mathrm{m} 2)$

$\mathrm{C}=$ coefficient of runoff rain water from the roof

$\mathrm{I}=$ rain intensity $(\mathrm{m} /$ hour $)$

\section{Determine geometric factors}

The geometric factor value $(\mathrm{F})$ is determined where the infiltration well is planned to be located in a completely porous land with all permeable well walls and a half-ball bottom:

$$
\begin{aligned}
& F=\frac{2 \pi H+\pi^{2} R \ln 2}{\ln \left\{\frac{H+2 R}{3 R}+\sqrt{\left(\frac{H}{3 R}\right)^{2}}+1\right\}} \\
& F=\frac{2 \times 3,14 \times 2+3,14^{2} \times 0,5 \ln 2}{\ln \left\{\frac{2+2 \times 0,05}{3 \times 0,5}+\sqrt{\left(\frac{2}{3 \times 0,5}\right)^{2}}+1\right\}} \\
& F=9,2 m
\end{aligned}
$$

Description:

$\mathrm{H}=$ water level in wells $(\mathrm{m})=2 \mathrm{~m}$

$\mathrm{R}=$ well radius $(\mathrm{m})=0.5 \mathrm{~m}$

$\mathrm{F}=$ geometric factor of circle appearance $(\mathrm{m})$

Determine the amount of Infiltration Wells

$\mathrm{Q}=\mathrm{F} \times \mathrm{K} \times \mathrm{H}$

$H=\frac{Q}{F \times K}$

$H=\frac{0,0555}{9,2 \times 1,75 \times 10^{-5}}$

$H=344,5 \mathrm{~m}$ 
Amount of Infiltration Wells

$n=\frac{H}{2}$

$n=\frac{344,5}{2}$

$n=172$ pieces

Runoff discharge absorbed by the presence of infiltration wells is:

$\mathrm{Q}=172$ pieces $\times 1,135 \mathrm{~m}^{2} /$ hour

$\mathrm{Q}=195.22 \mathrm{~m}^{2} /$ hour $=0.054 \mathrm{~m}^{2} / \mathrm{sec}$

This means that, almost all runoff water can be reduced by infiltration wells.

Plan runoff discharge $\mathrm{Q}=0.0555 \mathrm{~m} 3 / \mathrm{sec} \approx \mathrm{Q}=0.054 \mathrm{~m} 3 / \mathrm{sec}$

However, due to the unavailability of the open land to make 172 infiltration wells, it is planned to be made along the edge of the road in three locations of the basin that often occur inundation. with a distance of 1 meter between holes, then:

Number of holes per location

$$
\mathrm{n}=172 / 3
$$$$
\mathrm{n}=58 \text { pieces }
$$

Infiltration wells can be installed on the left and right sides of the road, where the number of infiltration wells on each side is 29 units. This amount will be reduced if each building along this area applies infiltration wells in their respective buildings. The following examples of recharge wells used can be seen in the image below.

\section{CONCLUSIONS AND RECOMMENDATIONS \\ 4.1 Conclusion}

Based on the results of the analysis, it can be concluded that

1. From the rainfall data, it is obtained that the rainfall in the rainfall plan with a 2 -year return period is $\mathrm{Q}=0.0555 \mathrm{~m} 3 / \mathrm{sec}$ with rain intensity $\mathrm{I}=2,276 \mathrm{~mm} /$ hour

2. To reduce the runoff discharge by $\mathrm{Q}=0.0555 \mathrm{~m} 3 / \mathrm{sec}, 172$ infiltration wells are needed with a size of depth $\mathrm{H}=2 \mathrm{~m}$ and well radius $\mathrm{R}=0.5 \mathrm{~m}$

3. The required infiltration wells are 172 pieces, can be divided into 3 locations with the number of each location is 58 units, if in each location infiltration wells are made on the left and right side of the road then it takes as many as 29 infiltration wells on each side for each location.

\subsection{Suggestion}

1. The amount of recharge obtained with the assumption, all rain water is channeled to the highway. but the number of recharge wells needed can be reduced if in each building in the TDM area can apply / make infiltration wells in their respective buildings

2. Regulations are required to be stablished so that each building must have its own infiltration well, in order to reduce the amount of runoff water to reduce the wasted water and causes disasters. 


\section{References}

[1] Agus Maryono : Eko-hidraulik pembangunan sungai: menanggulangi banjir dan kerusakan lingkungan wilayah sungai, Universitas Gadjah Mada (2002)

[2] Kustamar : Strategi Pengendalian Banjir di kawasan permukiman padat. Jurnal pada Buletin Utama Teknik Vol. 14, No. 1, September (2018)

[3] Aji Aflakhi, Venni Budi Cahyani, Dwi Kurniani, Hary Budieny; Perencanaan EkoDrainase Kawasan Perumahan Tembalang Pesona Asri - Semarang, Jurnal pada JURNAL KARYA TEKNIK SIPIL, Volume 3, Nomor 2, Tahun 2014, Halaman 436 442 ; Online di: http://ejournal-s1.undip.ac.id/index.php/jkts (2014)

[4] Badan standardisasi Nasional, SN1 03-2453-2002 Tata cara perencanaan sumur resapan air hujan untuk lahan pekarangan, Jakarta (2002)

[5] Suripin : Drainase Perkotaan yang Berkelanjutan, Andi, Yogyakarta (2004)

[6] Kamiana, I Made : Teknik Perhitungan Debit Rencana Bangunan Air, Graha Ilmu, Yogyakarta (2011)

[7] Hasmar Halim, H., A.: Drainase Terapan, UII Press, Yogyakarta (2011)

[8] Sri Harto, Br : Analisis Hirologi, Gramedia (1993) 